\title{
螺旋空間を利用した新規不斉リン配位子の開発と不斉触媒反応への応用
}

\author{
臼井一晃
}

\section{Development of New Chiral Phosphine Ligands with Helical Environments and Their Application in Asymmetric Catalytic Reactions}

\author{
Kazuteru Usui \\ Graduate School of Pharmaceutical Sciences, Kyushu University; \\ 3-1-1 Maidashi, Higashi-ku, Fukuoka 812-8582, Japan.
}

(Received June 27, 2017)

\begin{abstract}
The design and development of new chiral ligands to enable precise stereocontrol in a wide variety of reactions is one of the most important branches of organic synthesis. To date, the development of hybrid ligands containing both $\sigma$ donating and $\pi$-donating groups has attracted considerable attention, with unprecedented reactivities and stereoselectivities being observed. Therefore to develop efficient hybrid chiral ligands with novel structural motifs, we envisage that helicene would be a suitable $\pi$-donor efficiently to construct a helical environment around a metal center. In this context, we herein describe our recent efforts to develop a series of novel chiral [5] helicene-derived phosphine ligands (L1, with a 7,8-dihydro [5] helicene core structure, and $\mathbf{L 2}$, with a fully aromatic [5] helicene core structure). The prepared ligands, and in particular L1, were found highly effective in the asymmetric allylation of 1,3-diphenylallyl acetate with indoles and etherification with alcohols. Furthermore, in the asymmetric Suzuki-Miyaura coupling reaction, L2 exhibited excellent enantioselectivities. Finally, density functional theory studies were employed to propose a model that accounts for the origin of such high enantioselectivity in these reactions.
\end{abstract}

Key words — - helicene; helix; phosphine ligand; asymmetric allylation; Suzuki-Miyaura cross-coupling

\section{1. はじめに}

触媒的不斉合成法は，効率よく光学異性体をつく り分ける無駄の少ない合理的な技術であり，これま でにBINAP に代表されるようなへテロ原子を配位 点とする様々な不斉配位子の利用が一般的であっ た. ${ }^{1,2)}$ これら従来型の不斉配位子に加えて，近年は 金属との $\pi$ 錯体の形成が可能なアルケンやアレー ンを配位部位として含む不斉配位子が注目されてい る. ${ }^{3-6)}$ なかでも，2つの配位点に異なる電子的性質 （ $\sigma$ 電子供与性と $\pi$ 電子供与性）を有するハイブ リッド型配位子を用いた遷移金属触媒において，従 来にない反応性や立体選択性が発現することが見い 出されている. ${ }^{7-15)}$ このような背景の下, 筆者ら は，堅牢な螺旋 $\pi$ 共役構造と特異な電子環境を兼 ね備えるヘリセン分子に着目し，これを不斉素子と

九州大学大学院薬学研究院（T812-8582 福岡市東区馬 出 3-1-1)

e-mail: usui @ phar.kyushu-u.ac.jp

本総説は, 平成 28 年度日本薬学会九州支部学術奨励賞

の受賞を記念して記述したものである.
した新たなハイブリッド型不斉配位子の開発を着想 した. ヘリセンは，複数の芳香環がオルト位で縮環 した多環式芳香族化合物群の総称であり，キラル機 能性材料を始めとして不斉配位子・触媒としての幅 広い応用が期待されている. ${ }^{16-23)}$ それゆえに，既に 多くの合成例が報告されているが，適切な位置に特 定の官能基を導入できる精密合成法の開発は，ヘリ センの機能創出の面で重要な課題である.

筆者は，2009 年度より，ヘリセン分子の螺旋キ ラリティーを利用した多角的な応用研究を目指し, これまでに塩化白金触媒を用いたアルキンの環化異 性化反応によって, 螺旋構造内部 1 位に官能基を有 する [5]ヘリセン (螺旋構造内部置換型 [5]ヘリセン) の構築とそれらの諸物性を明らかにしてきた. ${ }^{24,25)}$ 螺旋構造内部に官能基を有するへリセン類はキラル 配位子や不斉有機分子触媒の基本構造として注目さ れており, 螺旋構造内部置換型 [5]ヘリセンを効率 的に合成できる手法を開発できたことは，これを基 盤とした新たな配位子設計・合成を進める上で大き な突破口となった. 


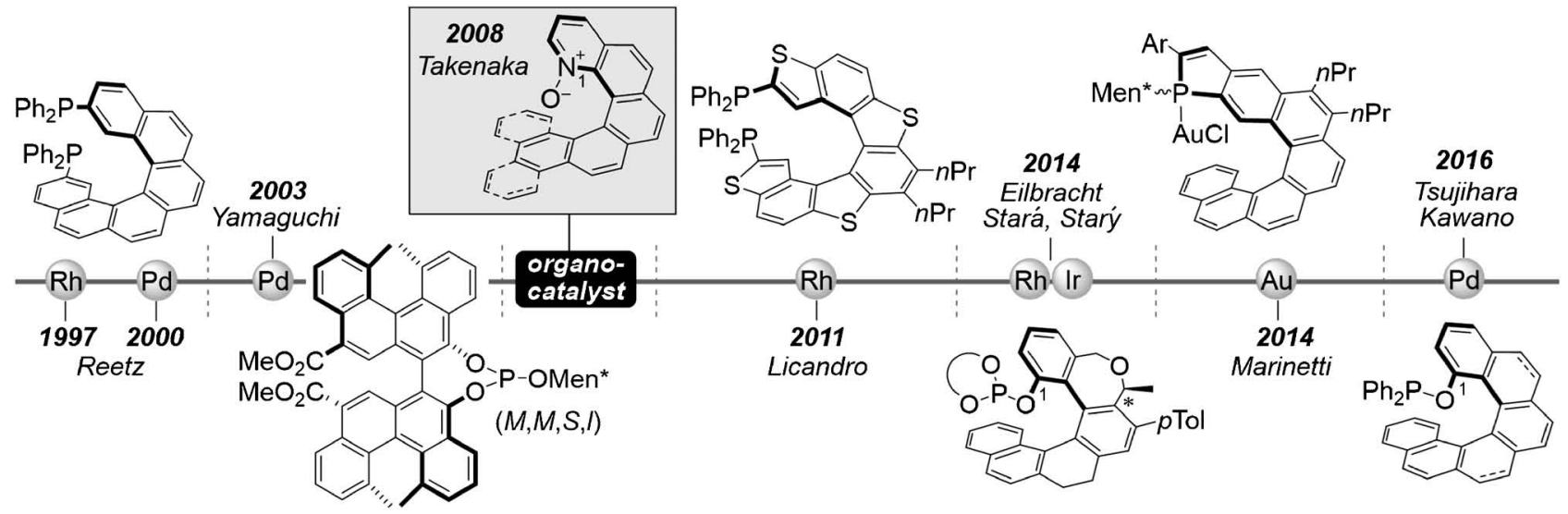

Fig. 1. Timeline Representing the Development of Various Chiral Helicene-based Phosphorous Ligands That Are Suitable for Use in Asymmetric Catalytic Reactions

本総説では，上記方法を鍵工程とした [5]ヘリセ ン型ホスフィン配位子の設計・合成，単結晶 $\mathrm{X}$ 線 構造解析及び諸物性を概説し，得られた配位子の不 斉パラジウム触媒反応への利用について紹介する.

\section{2. [5]ヘリセン型ホスフィン配位子の設計と合} 成

2-1. ヘリセン型リン配位子の背景と設計概念 ヘリセンを不斉リン配位子として利用した例は, Reetz らによる先駆的な研究を含め，数々の不斉配

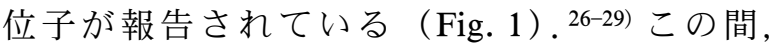

Takenaka らは，メソエポキシドの触媒的不斉開環 反応において 1-アザヘリセン $N$-オキシド触媒が優 れた立体選択性を与えることを明らかとし，螺旋構 造内部空間を反応場とする分子設計の重要なマイル ストーンとなった. ${ }^{30)}$ その後, Starý ら, Marinetti ら，及び Tsujihara らによっても螺旋構造内縁側に ホスファイト基, ホスホール環, 及びホスフィナイ 卜基をそれぞれ有するキラルリン配位子が，各種不 斉遷移金属触媒反応において有効であることが示さ れている. ${ }^{31-33)} こ の よ う に$ 螺旋構造内縁部に配位点 を有する数々の分子が報告されているが，螺旋中心 軸に最も近い 1 位にリン原子を導入した配位子はい まだ合成されていなかつた.

このような背景から，筆者は，従来にない論理的 かつコンパクトな配位子として，[5]ヘリセンの螺 旋構造内部 1 位に配位性官能基であるホスフィノ基 を有するキラル配位子を設計した [Fig. 2(a) ]。こ れまで開発されてきた配位子の多くは右巻き $(P)$ と左巻き $(M)$ の相互変換（ラセミ化過程）に対 し，高い反転障壁を有する縮合環数（6 以上）の多
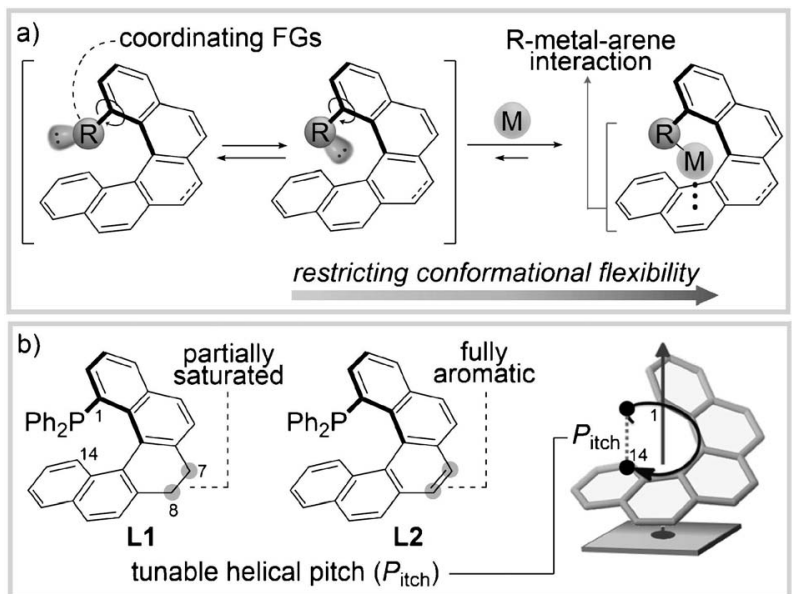

Fig. 2. Design of [5] Helicenylphosphine Ligands Based on Metal-arene Interactions

いヘリセン骨格を用いていることが特徽として挙げ られる。一方，本配位子は，1位に直結するホス フィノ基と末端に位置する芳香環との立体障害に よって立体反転が制約されるため，[6]ヘリセンと 同程度のラセミ化耐性を有することが見込まれ る. ${ }^{24,34)}$ さらに，ホスフィンに加えて，ヘリセンの $\pi$ 共役面も金属に対する配位点として機能すること が予想され, リンー炭素単結合軸の自由回転の制限 のみならず中心金属の電子構造と不斉環境を高度に

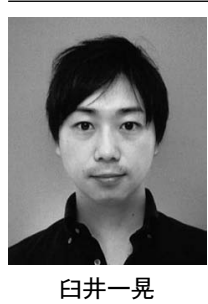

九州大学大学院薬学研究院・助教 博 士 (薬学). 北海道出身. 2008 年九州 大学大学院薬学府創薬科学専攻博士課 程修了（末宗 洋教授），2008 年米国 スタンフォード大学化学科博士研究員 (Eric T. Kool 教授)，2009 年 4 月より 現職. 2016 年日本薬学会九州支部学術 奨励賞受賞. 専門は有機化学. 


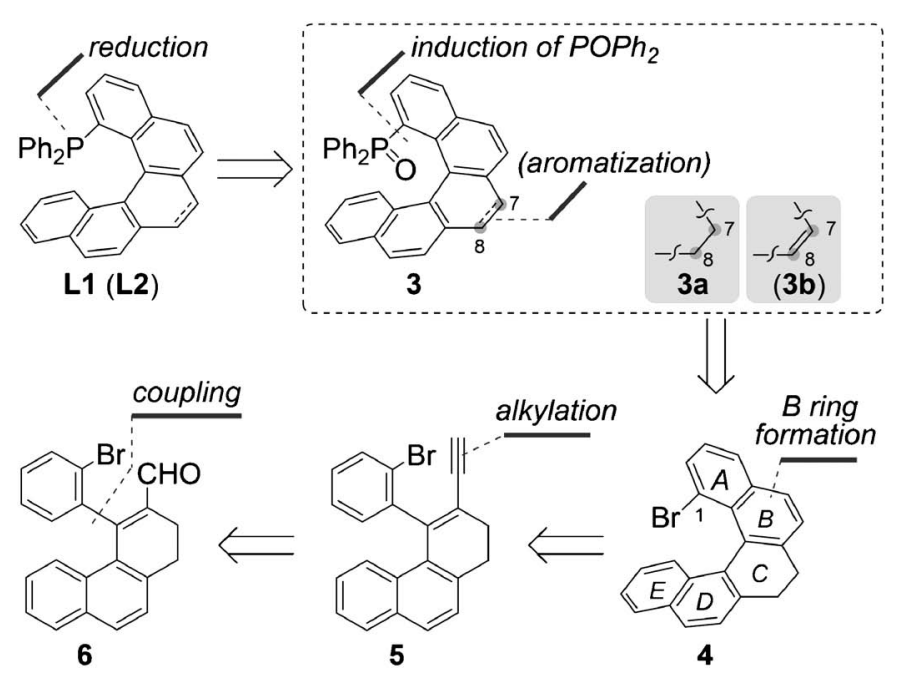

Scheme 1. Retrosynthetic Analysis of [5] Helicenylphosphine Ligands

制御できる配位子としての機能が期待できる.

具体的には, “7,8- ジヒドロ [5]ヘリセン型ホス フィン配位子 L1” 及び“[5]ヘリセン型ホスフィン 配位子 L2”を設計した [Fig. 2(b) ]。これら配位 子は，中心金属に配位した基質の配座自由度や電子 構造が異なることが想起されるため，目的とする反 応に応じてこれら配位子を使い分けることができる ものと考えた.

2-2. [5]ヘリセン型ホスフィン配位子の合成 ホスフィン配位子 $\mathbf{L 1}$ 及び $\mathbf{L} 2$ の構造的類似性に 着目し，7,8- ジヒドロ [5]ヘリセン 3 を共通中間体 とする合成計画を立てた（Scheme 1)。すなわち， 1 位にホスフィンオキシドを有する 3 を共通中間体 とし，これを光学分割した後，ホスフィンオキシド 部を還元処理することで光学活性なホスフィンに導 けると考えた。 また，3は1-ブロモジヒドロ [5]へ リセン 4 の臭素原子を足掛かりとした直接的な官能 基変換により合成できると想定した．分子全体に大 きな歪みがある 4 をいかに構築するかが鍵となる が，アルデヒド $\mathbf{6}$ から変換可能なアルキン $\mathbf{5}$ の塩化 白金 $\left(\mathrm{PtCl}_{2}\right)$ 触媒による環化異性化反応によって 合成することを計画した。

前述の合成戦略に基づき, 配位子の合成を検討し た (Scheme 2). まず，市販のナフタレンと無水コ ハク酸との Friedel-Crafts アシル化反応により $\beta$ 置 換体 7 を合成した。これを Wolff-Kishner 還元する ことで得られた $\mathbf{8}$ を，メタンスルホン酸中加熱する ことで環状ケトン体 9 に変換し，さらに Vilsmeier-
Haack 反応によってクロロホルミル体 $\mathbf{1 0}$ に導い た。得られた 10 と2-ブロモフェニルボロン酸 11 のリガンドフリーなクロスカップリング反応では, 高化学選択的に反応が進行し, 期待した以上の収率 で 6 を得ることができた。パラジウム触媒クロス カップリング反応における酸化的付加の化学選択性 は炭素ーハロゲン $(\mathrm{C}-\mathrm{X})$ 結合の結合解離エネルギー (bond dissociation energy; BDE) に大きく依存す る. ${ }^{35)}$ 密度汎関数理論 (DFT) 計算により炭素一ハ ロゲン結合の $\mathrm{BDE}$ を計算した結果， 10 の $\mathrm{C}-\mathrm{Cl}$ 結 合の $\operatorname{BDE}(\Delta H=78.9 \mathrm{kcal} / \mathrm{mol})$ は 11 の-Br 結 合のそれよりも $1.5 \mathrm{kcal} / \mathrm{mol}$ ほど低く見積もられ た。これは $\mathrm{C}-\mathrm{Cl}$ 結合に対して 0 価パラジウムが選 択的に酸化的付加し易い電子状態にあることを示唆 しており，隣接するホルミル基の電子吸引性効果に よるものと考えられる. ${ }^{36)}$

続いて，6 Ohira-Bestmann 試薬によりアルキ ン 5 に変換後, $\mathrm{PtCl}_{2}$ 触媒による環化異性化反応条 件に付すことで $\mathrm{B}$ 環部を構築し，ジヒドロ [5]ヘリ セン構造を有する rac-4 (ラセミ体) を得た。つい で, sec-BuLi とクロロジフェニルホスフィンを順 次作用させた後に, 過酸化水素で処理することで所 望の共通中間体 $r a c-3 a$ を合成した.

Keglevich らによるホスホレン1-オキシド体の分 別結晶化法を基に, ${ }^{37)}$ 様々な光学分割剂や分割条件 を変えて rac-3a の分別結晶化を検討した。その結 果, アセトニトリル中, 光学分割剤として spiroTADDOL 誘導体 (-)-12 を用いることで光学純度 

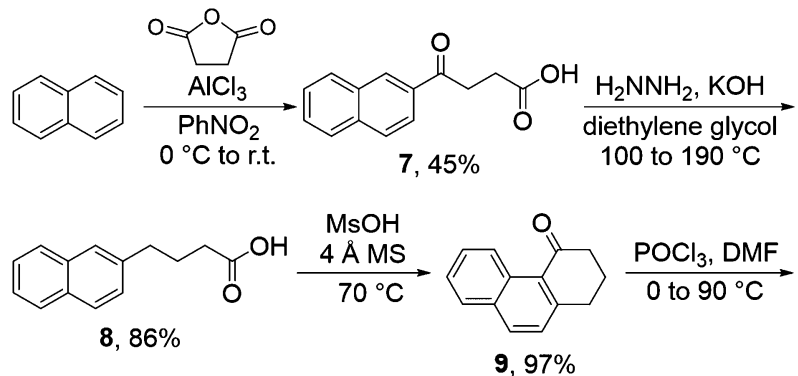

BDEs ( $\mathrm{kcal} / \mathrm{mol})$ - -
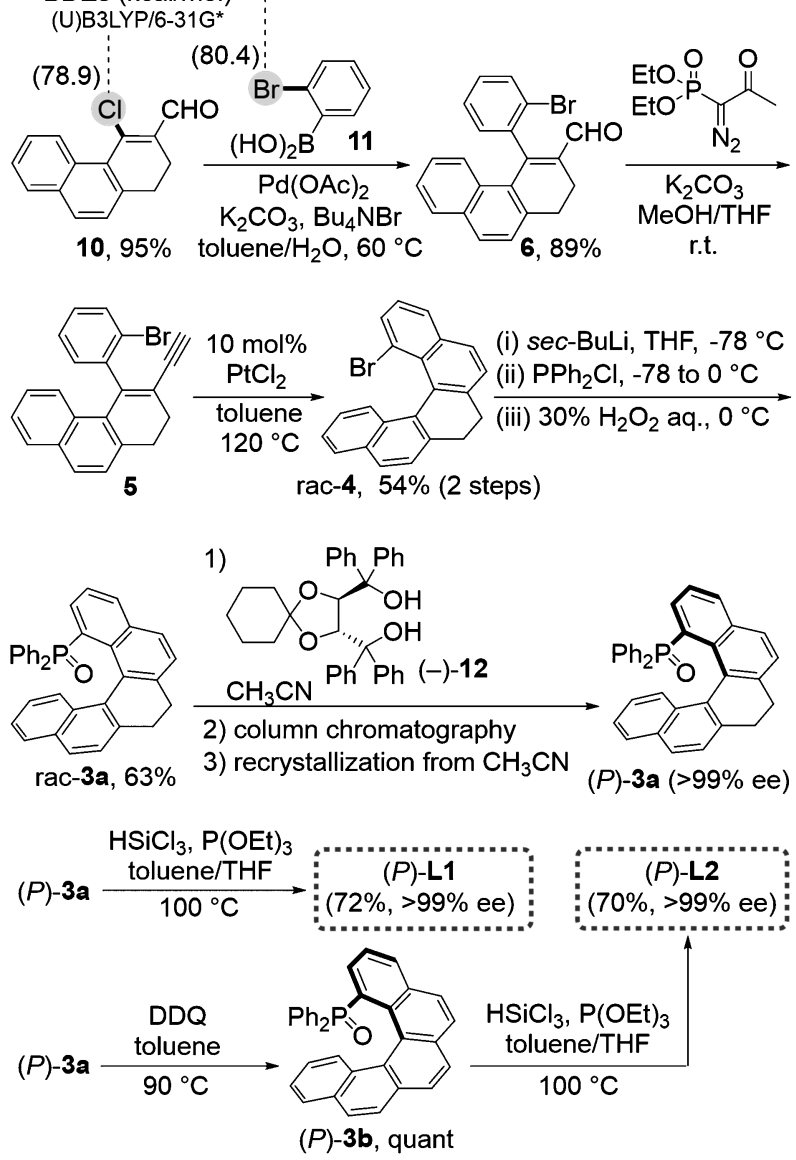

Scheme 2. Synthesis of Chiral Phosphines $\mathbf{L 1}$ and $\mathbf{L 2}$

の高い $(P)-3 \mathbf{a}(>99 \%$ ee) を調製することができた. 最後に, 光学活性 $(P)$-L1 は $(P)$-3a をトリクロロ シランとトリエチルホスファイトを用いた還元条件 に付すことで導いた。一方， $(P)$-L2 は $(P)-3 \mathbf{a} の$ DDQ による酸化的芳香族化と続く $(P)-\mathbf{3 b}$ の還元 により合成することに成功した. ${ }^{38)}$

配位子の絶対配置は，円二色性（CD）スペクト ルを測定することで決定した．Fig. 3 にCD スペク トルの測定結果を示す。ジヒドロ [5]ヘリセン構造 を持つ配位子 L1 では, $(P)-(+)$ 体が $260 \mathrm{~nm}$ 付近 に正の極大を, $220 \mathrm{~nm}$ 付近に負の極大を示した.

[5]ヘリセン構造を有する配位子 L2 においては, a)

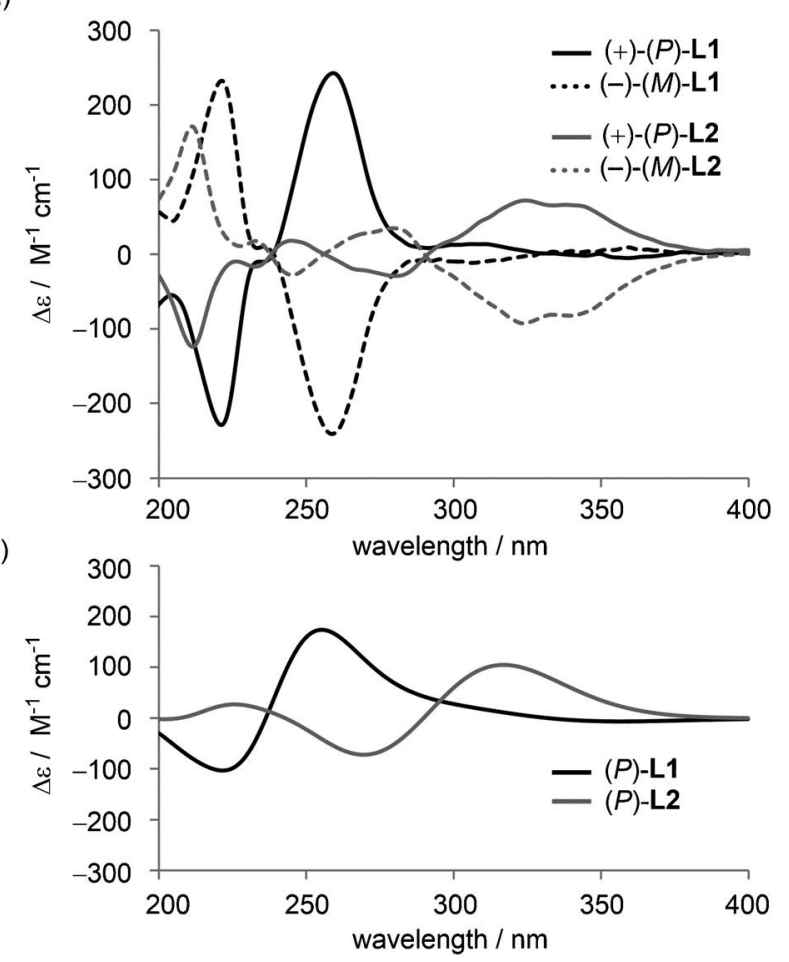

Fig. 3. Experimental and Calculated CD Spectra

(a) CD spectra of $(P)$-L1 (black solid line), $(M)$-L1 (black dashed line), $(P)$-L2 (gray solid line), and $(M)$-L2 (gray dashed line) in acetonitrile $\left(1.0 \times 10^{-5} \mathrm{M}\right)$. (b) Calculated (CAM-B3LYP/6-31+G**//B97-D/ 6-31G*) CD spectra of $(P)-\mathbf{L 1}$ (black solid line) and $(P)$-L2 (gray solid line).

$(P)-(+)$ 体が $325 \mathrm{~nm}$ 付近に正の極大を, $280 \mathrm{~nm}$ 付近に負の極大を示した。さらに時間依存密度汎関 数理論（Time-Dependent DFT）計算により CD ス ペクトルの理論的予測を行ったところ，実測值とよ い一致を示した.

2-3. 配位子のルイス塩基性評価 ホスフィン 配位子 $\mathbf{L 1}$ 及び $\mathbf{L} 2$ について, 電子供与性を評価し た．ホスフィンの電子供与性を測定するための方法 の 1 つに ${ }^{31} \mathrm{P}-{ }^{77} \mathrm{Se}$ のカップリング定数 ( ${ }^{1} J_{\mathrm{P}-\mathrm{Se}}$ 值 $)$ を比較する方法が挙げられる。 Taylor らは, リン 原子上の孤立電子対の $\mathrm{s}$ 性が強くなり電気陰性度が 高くなるにつれて (Bent 則)，言い換えるとルイス 塩基性が低いほど ${ }^{1} J_{\mathrm{P}-\mathrm{Se}}$ 值が相対的に大きくなるこ とを提唱した。 ${ }^{39)} \mathbf{L 1}$ 及び L2 に対応するホスフィン セレニド錯体を調製後， ${ }^{1} J_{\mathrm{P}-\mathrm{Se}}$ 值を ${ }^{31} \mathrm{P} \mathrm{NMR}$ で測定 した結果， $\mathbf{L 1}$ は ${ }^{1} J_{\mathrm{P}-\mathrm{Se}}=749 \mathrm{~Hz}(\delta \mathrm{P}(\mathrm{v}) 37.0 \mathrm{ppm})$, L2 では ${ }^{1} J_{\mathrm{P}-\mathrm{Se}}=771 \mathrm{~Hz}(\delta \mathrm{P}(\mathrm{v}) 37.9 \mathrm{ppm})$ を示した ことから, リン原子上の電子密度が $\mathbf{L} 2$ の方が低い ことが明らかとなった。このことから，一般的な遷 移金属触媒反応でみられる金属の酸化状態変化を伴 
a)

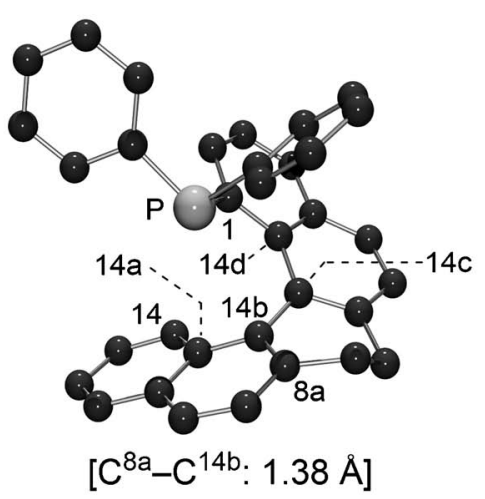

L1

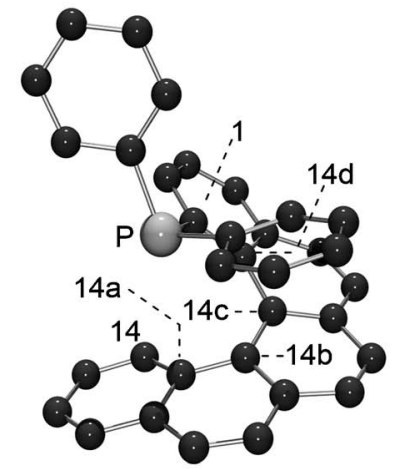

L2

b)

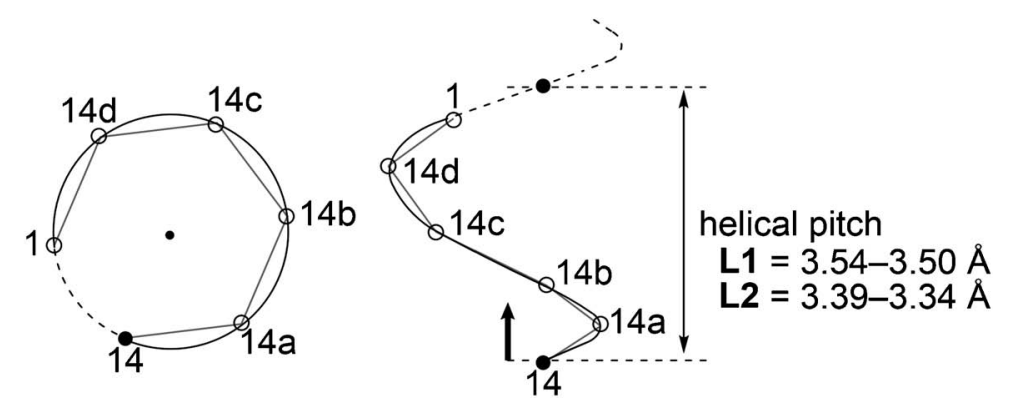

Fig. 4. X-ray Crystal Structures and Their Helical Pitch Values

(a) X-ray structures of $\mathbf{L 1}$ and $\mathbf{L} 2$; the hydrogen atoms are omitted for clarity. (b) The helical pitch diameter of the ligands calculated using the 3D coordinates of the inner carbon atoms $\left(\mathrm{C}^{14}, \mathrm{C}^{14 \mathrm{a}}, \mathrm{C}^{14 \mathrm{~b}}, \mathrm{C}^{14 \mathrm{c}}, \mathrm{C}^{14 \mathrm{~d}}\right.$, and $\left.\mathrm{C}^{1}\right)$. The left and right diagrams show the view along the helical axis and the side view of a $(P)$-helicene, respectively.

う過程のうち， L1 は L $\mathbf{2}$ よりも酸化的付加に有利 で，L2 は L1 よりも還元的脱離の過程に有利であ ると考えられる。

2-4. 配位子及び 0 価パラジウム錯体の単結晶 $\mathbf{X}$ 線構造解析と理論的考察配位子 $r a c-\mathbf{L 1}$ 及び $r a c$-L2 を用いて $\mathrm{CH}_{2} \mathrm{Cl}_{2}$-hexane 混合溶液から再結 晶することで単結晶試料が得られた。単結晶 $\mathrm{X}$ 線 構造解析を行ったところ，それぞれ空間群 $P-1$ に 属する結晶であった [Fig. 4(a)]，続いて，ヘリセ ンの螺旋骨格内縁部に位置する炭素原子座標につい てフィッティングを行い, 螺旋のピッチ長を定量的 に見積もった。その結果，予想通り L1 (3.54-3.50 A）の方が L2 (3.39-3.34 Å) よりもピッチ長が伸び た螺旋構造を形成していることが明らかとなった [Fig. 4 (b) ]。この差は，触媒反応において，螺旋 軸周りの基質の空間的な配置に影響を与えることが 予想される.

続いて，パラジウムとの錯体構造中での配位子の 立体配座と，リンーパラジウムーアレーン相互作用を 検証するため, $r a c-\mathbf{L 1}$ を用いて 0 価パラジウム錯 体の構造解析を試みた。 $r a c-\mathbf{L 1}$ と $\mathrm{Pd}_{2}(\mathrm{dba})_{3}$ ・
$\mathrm{CHCl}_{3}$ を $\mathrm{THF}$ 中, $50^{\circ} \mathrm{C}$ で加熱後，カラムクロマト グラフィーによる精製，続くアセトンからの再結晶 によりパラジウムに対して L1 とジベンジリデンア セトン（dba）が 1：1 で配位した 0 価パラジウム 錯体 13 の単結晶を得ることに成功した．構造解析 の結果，期待通りパラジウムは，リン原子のみなら ず，ヘリセン骨格中の核間炭素 $\mathrm{C}^{8 \mathrm{a}}, \mathrm{C}^{14 \mathrm{~b}}$ と $\eta^{2}$ 型で 配位していることが明らかとなった [Fig. 5(a)]. $\mathrm{C}^{8 \mathrm{a}} \mathrm{C}^{14 \mathrm{~b}}$ 結合距離はメタルフリーのものよりも長く なっており [Fig. 4(a)vs. 5(a)]，この変化は Dewar-Chatt-Duncanson モデルに従ってパラジウ

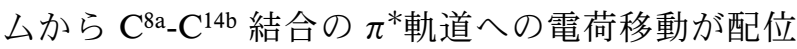
結合に含まれていることを示唆している。 そこで, 自然結合軌道（natural bond orbital; NBO）解析に

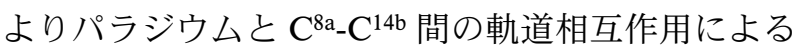
二次の摂動エネルギーを見積もつた結果，パラジウ

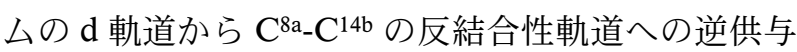
による值が， $\mathrm{C}^{8 \mathrm{a}} \mathrm{C}^{14 \mathrm{~b}}$ の結合性軌道からパラジウム の $\mathrm{d}$ 軌道への供与の值に比べて大きくなっている ことが示された $[$ Fig. 5(b)]。このことから， $\operatorname{Pd}(0)$ $[\mathbf{L 1}]$ 及び $\operatorname{Pd}(0)[\mathbf{L 2}]$ 錯体ではアレーン部の $\pi$ 受容 
a)

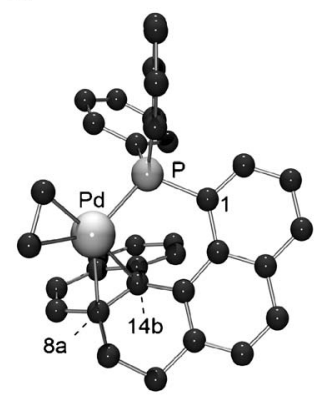

[C $\mathrm{C}^{\left.8 \mathrm{a}-\mathrm{C}^{14 b}: 1.42 \AA\right]}$

$\mathrm{Pd}(\mathrm{dba})[\mathbf{L} \mathbf{1}]$ complex 13 b)

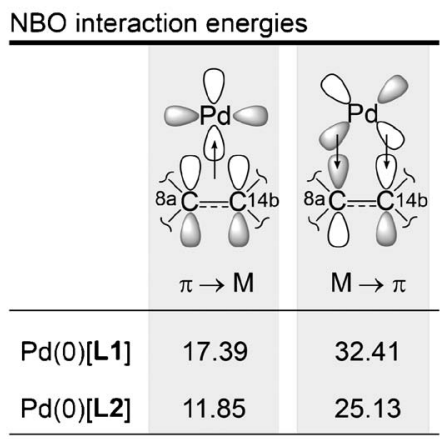

Fig. 5. X-ray Structure and DFT Calculation of $\operatorname{Pd}(0)[\mathbf{L}]$ Complex

(a) X-ray structure of $\mathrm{Pd}(\mathrm{dba})[\mathbf{L 1}]$ complex 13; the hydrogen atoms and dba are omitted for clarity. (b) B3LYP/6-311G*/LANL2DZ// B3LYP6-31G*/LANL2DZ calculated second-order perturbation energies $\left(E^{(2)}, \mathrm{kcal} / \mathrm{mol}\right)$ between the donor and acceptor NBOs of the $\operatorname{Pd}(0)[\mathbf{L 1}]$ and $\operatorname{Pd}(0)[\mathbf{L 2}]$ complexes.

体としての性格が比較的強い傾向にあると言える. このようなパラジウムーアレーン相互作用は，錯体 構造の安定化に寄与していると考えられ，螺旋空間 を反応場とする触媒システムへの展開に期待を抱か せた。

\section{3. 不斉触媒反応への適用}

3-1. パラジウム触媒不斉アリル位置換反応への 適用筆者らは，前章で合成した配位子 L1, L2 をパラジウム触媒不斉アリル位置換反応に適用し, それぞれの不斉配位子としの機能評価を行っ た. ${ }^{40-42)}$ 1,3-ジフェニルアリルアセテート 14 に対し て求核剤としてジメチルマロネート，さらにパラジ ウム触媒として $\pi$-アリルパラジウムクロリド二量 体 $\left[\mathrm{PdCl}\left(\mathrm{C}_{3} \mathrm{H}_{5}\right)\right]_{2}$, 塩基として炭酸セシウム $\left(\mathrm{CsCO}_{3}\right)$ を用いて，室温下で反応を検討した (Scheme 3)。その結果，どちらの配位子も定量的 に目的とする生成物を与え，特に L1 を用いたと き，高いエナンチオ選択性（99\%, 94\% ee）で所望 のアリル化成績体 $(R)-\mathbf{1 5}$ を与えた.

本反応における $\mathbf{L} 1$ の有用性を評価するため，そ の他の求核種を用い, それらの適用範囲を精査し た。まず，各種アルコールを求核種として用いた不 斉アリル位エーテル化反応を検討した [Table 1

(a)］。アリルアルコールを求核種とした場合を除い ては，良好な化学収率及び高い不斉収率を与えた。 続いて，創薬化学的に価值の高いインドールを求核 剤とした不斉アリル位置換反応を検討した。これま で，14に対してインドールを求核種とした場合,

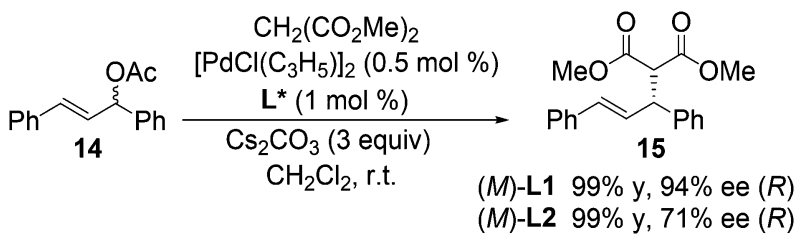

Scheme 3. The Pd-catalyzed Asymmetric Allylic Alkylation of 14

Table 1. Pd-catalyzed Asymmetric Allylation of Indoles and Etherification of Alcohols ${ }^{\text {a }}$

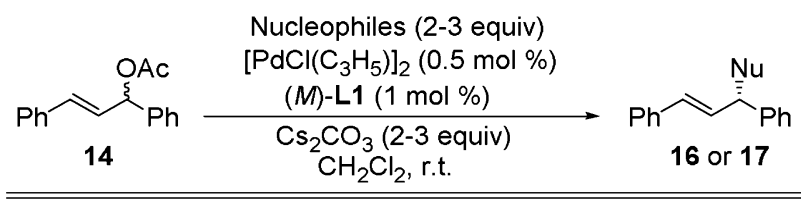

a) The substrate scope by using alcohols as nucleophiles ${ }^{\text {b }}$

$\begin{array}{lll}\text { 16a: } \mathrm{R}=\mathrm{Bn} & 95 \% \mathrm{y}, 96 \% \text { ee }(S) \\ \text { 16b: } \mathrm{R}=\mathrm{Me} & 80 \% \mathrm{y}, 93 \% \text { ee }(S) \\ \mathrm{Ph} & 84 \% \mathrm{y}, 90 \% \text { ee }(S) \\ \text { 16a-e } \mathrm{Rh}=\mathrm{Et} & 61 \% \mathrm{y}, 84 \% \text { ee }(S) \\ \text { 16d: } \mathrm{R}=\text { allyl } & 92 \% \mathrm{y}, 94 \% \text { ee }(S)\end{array}$

b) The substrate scope by using indoles as nucleophiles ${ }^{c}$

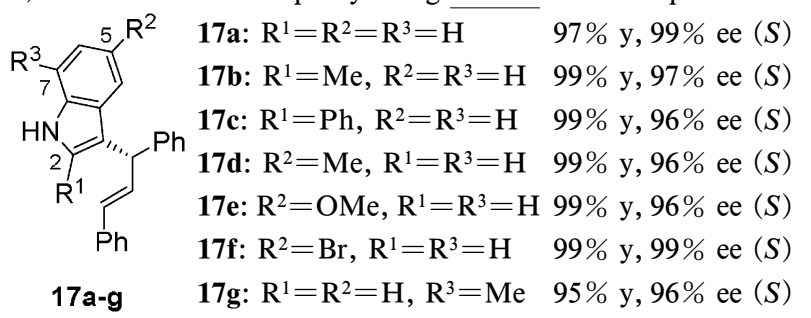

${ }^{a}$ Isolated yields. The ee values were determined by HPLC using a chiral column. The absolute configuration was determined by comparing the specific optical rotations with literature data. ${ }^{\mathrm{b}}$ Conditions for etherification: $14(0.15 \mathrm{mmol})$, alcohol $(0.45 \mathrm{mmol}), \mathrm{Pd} /(M)-\mathbf{L 1}=1.0(1 \mathrm{~mol} \%$ $\mathrm{Pd})$, and $\mathrm{Cs}_{2} \mathrm{CO}_{3}(0.45 \mathrm{mmol})$ in $\mathrm{CH}_{2} \mathrm{Cl}_{2}(0.75 \mathrm{~mL})$. ${ }^{\mathrm{c}}$ Conditions for allylation: $14(0.15 \mathrm{mmol})$, indole $(0.3 \mathrm{mmol}), \mathrm{Pd} /(M)-\mathbf{L 1}=1.0(1 \mathrm{~mol}$ \% $\mathrm{Pd})$, and $\mathrm{Cs}_{2} \mathrm{CO}_{3}(0.3 \mathrm{mmol})$ in $\mathrm{CH}_{2} \mathrm{Cl}_{2}(0.75 \mathrm{~mL})$.

高い化学収率と不斉収率を与える事例はごく限られ ており，Chanら，Duらによって見い出された非 対称構造を有するハイブリッド配位子を用いた反応 条件に留まっている. ${ }^{10,43)}$ 配位子 $\mathbf{L 1}$ を用いて各種 インドールとの反応を検討した結果，過去に報告さ れている類似反応に比べて本法が収率，立体選択性 ともに著しく優れていることが証明された [Table $1(\mathrm{~b})] .38)$

3-2. 不斉鈴木一宮浦カップリング反応への適用 筆者は，前節で述べた配位子 L1, L2 の有用性を さらに検証する目的で，不斉鈴木一宮浦カップリン グ（Suzuki-Miyaura cross-coupling; SMC） 反応に 展開した. ${ }^{44)}$ 螺旋不斉を不斉源とした軸不斉を誘起 
Table 2. Asymmetric Suzuki-Miyaura Coupling Using $(P)$ $\mathbf{L 1}$ and $(P)$-L2 ${ }^{\text {a }}$

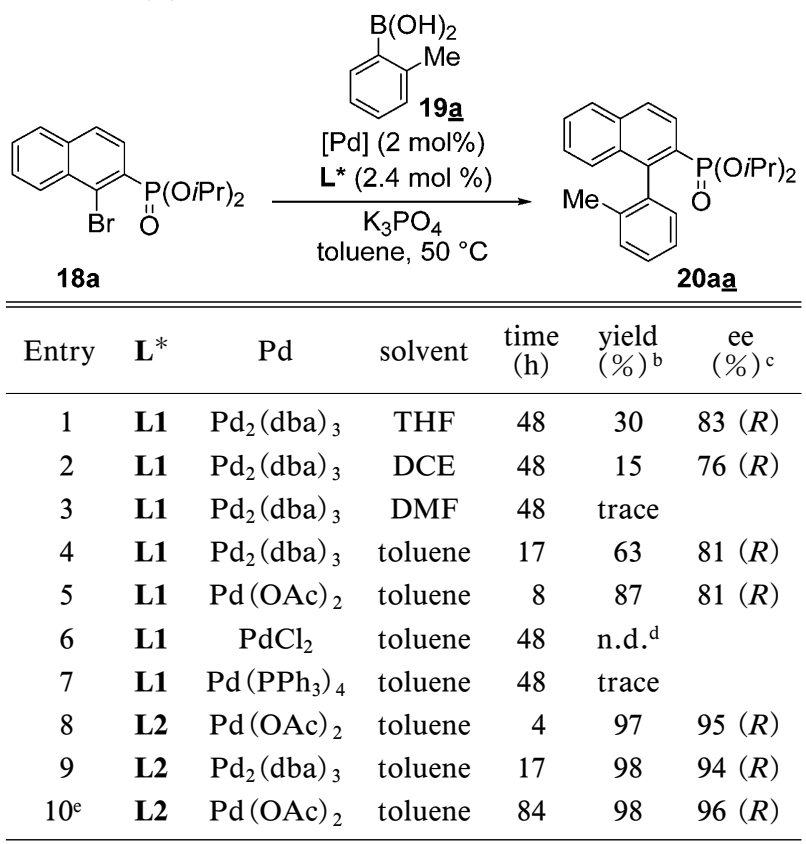

a Conditions: Aryl bromide 18a $(0.1 \mathrm{mmol})$, arylboronic acid 19a $(0.2$ $\mathrm{mmol}),(P)-\mathbf{L}^{*} / \mathrm{Pd}=1.2(2 \mathrm{~mol} \% \mathrm{Pd})$, and $\mathrm{K}_{3} \mathrm{PO}_{4}(0.3 \mathrm{mmol})$ in solvent $(0.5 \mathrm{~mL}), 50^{\circ} \mathrm{C}$. ${ }^{\mathrm{b}}$ Yields were determined by ${ }^{1} \mathrm{H}$ NMR analysis of the reaction mixture containing the dehalogenated product following purification by column chromatography. ${ }^{c}$ Determined by HPLC with a chiral column d No desired coupling product was detected. e Reaction carried out at $30^{\circ} \mathrm{C}$.
した例は極めて少なく, ${ }^{45)}$ ヘリセンの螺旋 $\pi$ 空間で の軸不斉誘起に興味が持たれる。不斉 SMC 反応に よるビアリール誘導体の合成研究の先駆例としては, 2000 年にフェロセン配位子を用いた Cammidge ら の報告46) と軸不斉ビナフチル配位子を用いた Buchwald らの報告が挙げられる.47)また， Buchwald らは，基質にパラジウムと相互作用する ヘテロ原子を導入することでエナンチ才選択性が大 幅に改善されることも報告している. ${ }^{47,48)}$ 近年では, Qin らやTang らによるリン中心性不斉配位子も不 斉 SMC 反応における立体選択性の発現に有用であ ることが示されている. ${ }^{49,50)}$

筆者らは，ホスホナート基を有する臭化アリール 18a とo-トリルボロン酸 19a とのカップリング反応 に対して， $(P)$ - $\mathbf{L 1}$ を用いて反応条件の最適化を 行つた (Table 2)。その結果, パラジウム触媒とし て酢酸パラジウム $\mathrm{Pd}(\mathrm{OAc})_{2}$, 溶媒としてトルエ ン, 塩基としてリン酸カリウム $\left(\mathrm{K}_{3} \mathrm{PO}_{4}\right)$ を用いて, $50^{\circ} \mathrm{C}$ で反応を行うことで，生成物 20aa のエナンチ 才選択性は $81 \%$ にまで向上した（Entries 1-4 vs. 5)。一方，L2 を本反応に用いた場合では，収率 97 \%, $95 \%$ ee と L1 と比べ反応性，エナンチオ選択 性共に大幅に向上した（Entries $5 v s .8)$ ．また，L2 を用いた場合では反応時間の延長を伴うものの 30

Table 3. Substrate Scope of the Pd-catalyzed Asymmetric Suzuki-Miyaura Coupling Reaction

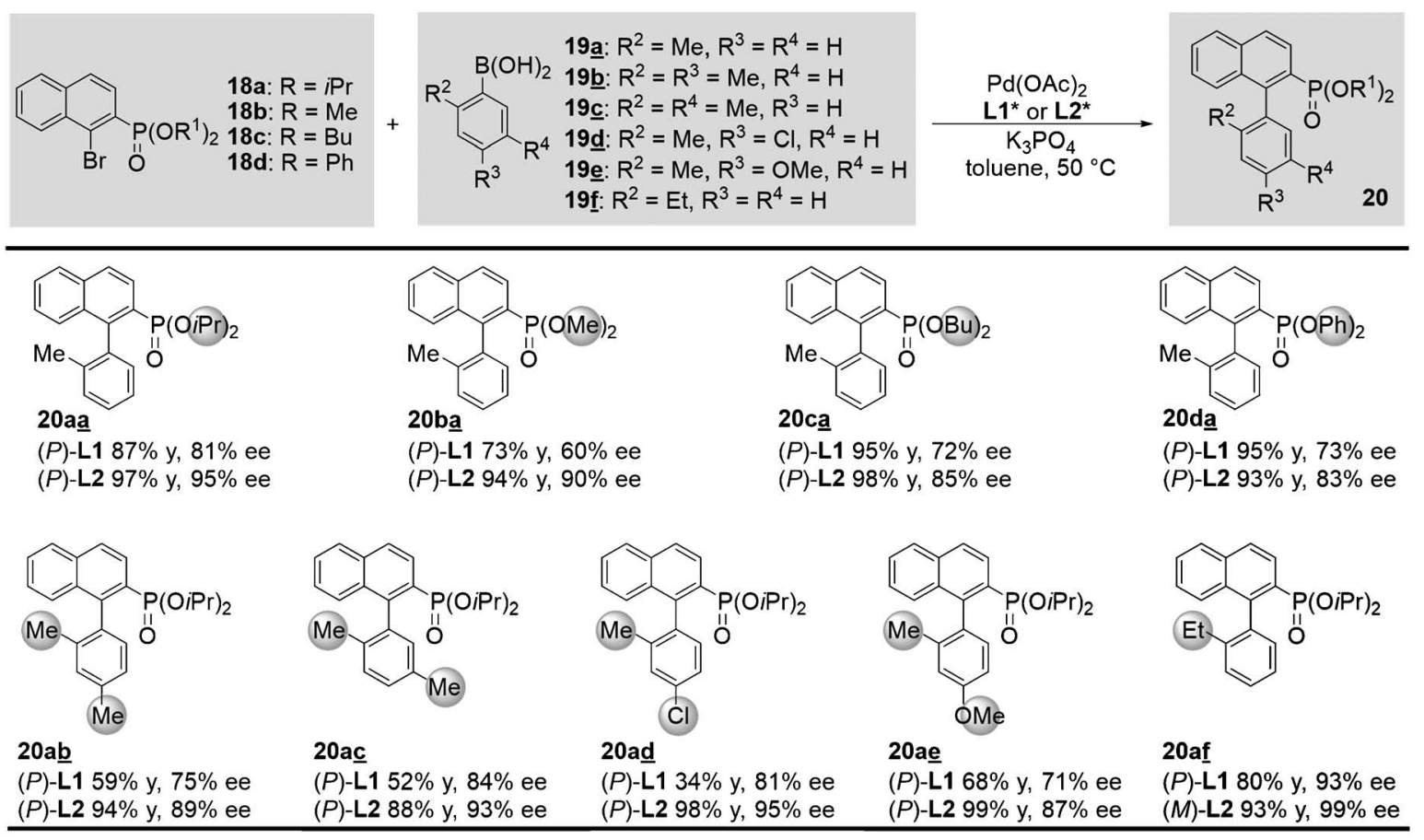


${ }^{\circ} \mathrm{C}$ でも反応が進行し，収率 $98 \% ， 96 \%$ ee という最 もよい結果を与えた（Entries $8 v s .10)$.

続いて, $50^{\circ} \mathrm{C}$ の条件を最適化条件として, 基質 適用範囲を検討した。様々なアリールブロマイド 18a-d と種々アリールボロン酸 19a-f とのカップリ ング反応を検討した（Table 3)，異なるホスホナー ト基を有するアリールブロマイド 18a-d とo-トリ ルボロン酸 19a とのカップリングでは, 所望の軸不 斉体（20aa-20da）を良好な化学収率かつ高い不斉 収率で得た。また，最も不斉収率の高かつた 18a と 種々アリールボロン酸 19b-f との反応を検討した結 果，特に $\mathrm{C}^{2}$ 位にエチル基を有する 19f を用いた場 合，不斉収率は $99 \%$ ee にまで向上した。興味深い ことに，前節で述べた不斉アリル位置換反応で観察 された結果とは逆に，本反応においてはへリセン型 の L2 がジヒドロヘリセン型の $\mathbf{L} 1$ よりも収率，工 ナンチ才選択性ともに高くなる傾向がみられた。 ${ }^{38)}$

3-3. 理論計算化学による不斉鈴木一宮浦カップ リング反応の立体選択性発現機構の解析 前節の 不斉 SMC 反応におけるへリセンの螺旋キラリ ティーによる不斉誘起メカニズム並びに配位子の効 果について理論的な解釈を得るため, エナンチオ選 択性が決定される還元的脱離過程における遷移状態 の計算を，DFT 法 (B97-D/6-31G*/LANL2DZ in toluene SMD) により行った。ここで配位子 $[(P)$ -L1，(P)-L2］の違いにより立体選択性に顕著な差 がみられた 18b と 19a の反応（20ba の形成）に着 目し，これを計算モデルとした，本反応では，パラ ジウム触媒に対する 18b の酸化的付加によって中 間体 IM-A-D が形成する [Fig. 6(a)］。このうちト ランス影響の大きなホスフィノ基とアリール基がシ スの関係になる 2 つの中間体 $\mathbf{I M}_{\mathbf{1}} \mathbf{- A}-\mathbf{B}$ からトラン スメタル化を経て，4 種のシス形錯体 $\left(\mathbf{I M}_{\mathbf{1}}-\mathbf{A}_{\text {ant } i}\right.$, $\left.\mathbf{I M}_{\mathbf{1}}-\mathbf{A}_{\text {syn }}, \mathbf{I M}_{\mathbf{1}}-\mathbf{B}_{\text {anti }}, \mathbf{I M}_{\mathbf{1}}-\mathbf{B}_{\text {syn }}\right)$ が主に形成されると 考えた．この仮定のもと，これらの還元的脱離過程 における各エナンチオマーへ通じる遷移状態を考慮 し，合計 8 種の遷移状態構造の探索を行った。その 結果，L1 を用いた系では 7 種，L2 を用いた系では 6 種の遷移状態が求められ，中でも $\mathbf{T S}_{\mathbf{6}}$ と $\mathbf{T S}_{7}$ が $S$ 体及び $R$ 体を与える最も安定な遷移状態になるこ とが示唆された。（P)-L1 を用いた場合では， $\mathbf{T S}_{\mathbf{6}}$ と $\mathbf{T S}_{7}$ のギブズ自由エネルギーの差は $0.9 \mathrm{kcal} / \mathrm{mol}$ であり， $(P)$-L2 を用いた場合では，その差が 2.1 a)

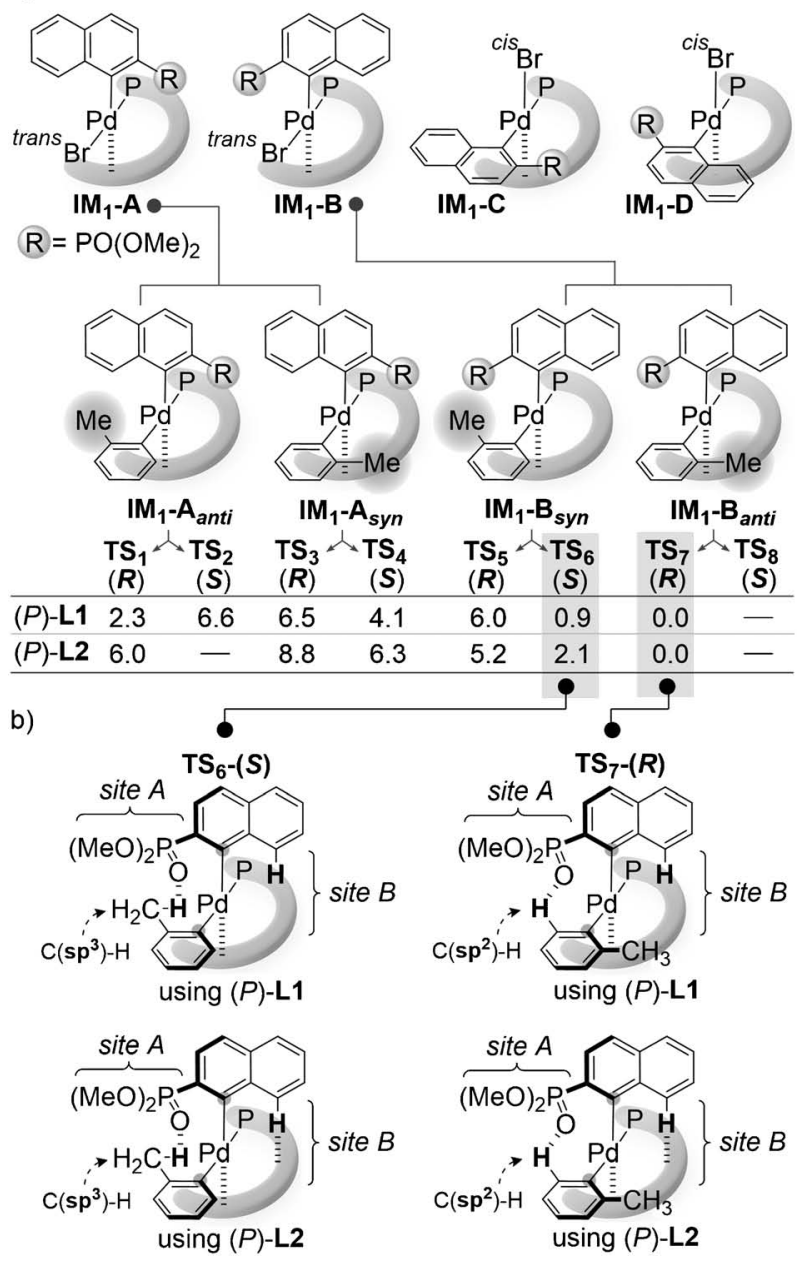

Fig. 6. Transition-state Structures and Activation Energies for the SMC Reactions

(a) Calculated relative Gibbs energy barriers $\left(\Delta \mathrm{G}_{r e l}, \mathrm{kcal} / \mathrm{mol}\right)$ in toluene at $298 \mathrm{~K}$ for the transition state structures. (b) Calculated transition state structures of $\mathbf{T S}_{6}$ and $\mathbf{T} \mathbf{S}_{7}$ using $(P)-\mathbf{L} \mathbf{1}$ and $(P)-\mathbf{L} \mathbf{2}$.

$\mathrm{kcal} / \mathrm{mol}$ と見積もられ，いずれも $R$ 体の生成が有 利になることが示唆された。これらのエネルギー差 は，遷移構造中のサイト $A$ でのトリル基の水素原 子と，ホスホナート基の $\mathrm{P}=\mathrm{O}$ 二重結合の酸素原子 との水素結合様式の違いによって説明される [Fig. 6(b)]。すなわち， $\mathrm{TS}_{7}$ で水素結合しているトリル 基ベンゼン環部の $\mathrm{sp}^{2}$ 水素は $\mathbf{T S}_{\mathbf{6}}$ で水素結合してい るメチル基の $\mathrm{sp}^{3}$ 水素より水素結合ドナーとしての 働きが強いためであると考えられる，さらに， $(P)$ -L2 を用いた場合，サイト $B$ において基質とへリセ ン $\pi$ 共役面との間で $\mathrm{CH} / \pi$ 相互作用も確認され た.この相互作用は基質の配座固定による立体化学 制御に有効に働いている可能性があり， $\mathbf{T S}_{6}-\mathbf{T S}_{7}$ 間 の相対エネルギー值が $\mathbf{L 1}$ よりも大きくなっている 要因として考えられる。これらのエネルギー差に基 
づくボルツマン分布から予想されるエナンチオマー 過剩率は実験事実に合致することからも，本計算方 法は極めて反応事象を精密に捉えていると言える [L1（実験值：60\% ee，計算值：62\% ee)，L2（実 験值：90\% ee，計算值：91\% ee)]. 以上，本研究 で得られた知見は，螺旋 $\pi$ 共役系を反応場とする 触媒の新たな設計指針になり得ることが期待される.

4. おわりに

以上のように筆者らは独自の作業仮説に基づい て，ヘリセンの螺旋 $\pi$ 共役構造を不斉素子とした 新規キラル配位子（L1, L2）の設計・合成に成功 した。 さらに，パラジウム触媒による不斉アリル位 置換反応及び不斉鈴木一宮浦カップリング反応への 展開を通じて，これら配位子が公知の配位子を凌駕 する高い不斉誘起能機能を有していることを明らか にした。また, 単結晶 X 線構造解析及び理論化学 計算によっても，ヘリセンの $\pi$ 共役面も配位部位 として機能することを解明し, 中心金属とへリセン $\pi$ 共役面との間で生じる相互作用が不斉触媒反応に おける反応性や立体化学制御に関与している重要な 知見を得ることができた.

本成果は螺旋構造を不斉場とする触媒が極めて有 効であることを示す proof-of-concept となるもので あり，医薬化学的利用価值が高い種々の光学活性誘 導体の創薬研究への展開が期待できる.

謝辞本稿で紹介した研究は, 九州大学大学院 薬学研究院薬物分子設計学分野にて行われたもので あり，終始温かいご指導，ご鞭撻を賜りました末宗 洋名誉教授に深謝申し上げます，有益なご議論と協 力を下さいました平井 剛教授, 九州大学先導物質 化学研究所の友岡克彦教授, 井川和宣助教に心より お礼申し上げます。また，本研究成果は共同研究者 の献身的な努力によって得られたものであり，山本 耕介博士（現 長崎大学大学院医歯薬学総合研究科 助教), 清水貴士氏を始めとする学生諸氏に心から 感謝いたします。最後に本研究は日本学術振興会の 科学研究費補助金 [若手研究 (B) 16K18846], 宇部 興産学術振興財団, 及び物質・デバイス領域共同研 究拠点からの援助により遂行されたものであり，関 係諸機関に感謝いたします。

利益相反＼cjkstart開示すべき利益相反はない.

\section{REFERENCES}

1) Yoon T. P., Jacobsen E. N., Science, 299, 1691-1693 (2003).

2) "Privileged Chiral Ligands and Catalysts," ed. by Zhou Q.-L., Wiley-VCH, Weinheim, 2011.

3) Glorius F., Angew. Chem. Int. Ed. Engl., 43, 3364-3366 (2004).

4) Johnson J. B., Rovis T., Angew. Chem. Int. Ed. Engl., 47, 840-871 (2008).

5) Defieber C., Grützmacher H., Carreira E. M., Angew. Chem. Int. Ed. Engl., 47, 4482-4502 (2008).

6) Shintani R., Hayashi T., Aldrichim. Acta, 42 , 31-38 (2009) .

7) Maire P., Deblon S., Breher F., Geier J., Böhler C., Rüegger H., Schönberg H., Grützmacher H., Chemistry, 10, 4198-4205 (2004).

8) Shintani R., Duan W.-L., Nagano T., Okada A., Hayashi T., Angew. Chem. Int. Ed. Engl., 44, 4611-4614 (2005).

9) Liu Z., Du H., Org. Lett., 12, 3054-3057 (2010) .

10) Cao Z., Liu Y., Liu Z., Feng X., Zhuang M., Du H., Org. Lett., 13, 2164-2167 (2011).

11) Kočovský P., Vyskočil Š., Císařová I., Sejbal J., Tišlerová I., Smrčina M., Lloyd-Jones G. C., Stephen S. C., Butts C. P., Murray M., Langer V., J. Am. Chem. Soc., 121, 77147715 (1999).

12) Barder T. E., Walker S. D., Martinelli J. R., Buchwald S. L., J. Am. Chem. Soc., 127, 4685-4696 (2005).

13) Pratap R., Parrish D., Gunda P., Venkataraman D., Lakshman M. K., J. Am. Chem. Soc., 131, 12240-12249 (2009).

14) Huang Z., Chen Z., Lim L. H., Quang G. C. P., Hirao H., Zhou J. S., Angew. Chem. Int. Ed. Engl., 52, 5807-5812 (2013).

15) Pregosin P. S., Coord. Chem. Rev., 252, 2156-2170 (2008).

16) Chen C.-F., Shen Y., "Helicene Chemistry: From Synthesis to Applications," Springer, Berlin, 2017.

17) Shen Y., Chen C.-F., Chem. Rev., 112, 14631535 (2012).

18) Gingras M., Chem. Soc. Rev., 42, 968-1006 
(2013).

19) Gingras M., Félix G., Peresutti R., Chem. Soc. Rev., 42, 1007-1050 (2013).

20) Gingras M., Chem. Soc. Rev., 42, 1051-1095 (2013) .

21) Bosson J., Gouin J., Lacour J., Chem. Soc. Rev., 43, 2824-2840 (2014).

22) Aillard P., Voituriez A., Marinetti A., Dalton Trans., 43, 15263-15278 (2014).

23) Narcis M. J., Takenaka N., Eur. J. Org. Chem., 21-34 (2014).

24) Yamamoto K., Okazumi M., Suemune H., Usui K., Org. Lett., 15, 1806-1809 (2013).

25) Usui K., Yamamoto K., Shimizu T., Okazumi M., Mei B., Demizu Y., Kurihara M., Suemune H., J. Org. Chem., 80, 6502-6508 (2015)

26) Reetz M. T., Beuttenmüller E. W., Goddard R., Tetrahedron Lett., 38, 3211-3214 (1997).

27) Reetz M. T., Sostmann S., J. Organomet. Chem., 603, 105-109 (2000).

28) Nakano D., Yamaguchi M., Tetrahedron Lett., 44, 4969-4971 (2003).

29) Monteforte M., Cauteruccio S., Maiorana S., Benincori T., Forni A., Raimondi L., Graiff C., Tiripicchio A., Stephenson G. R., Licandro E., Eur. J. Org. Chem., 5649-5658 (2011).

30) Takenaka N., Sarangthem R. S., Captain B., Angew. Chem. Int. Ed., 47, 9708-9710 (2008).

31) Krausová Z., Sehnal P., Bondzic B. P., Chercheja S., Eilbracht P., Stará I. G., Šaman D., Starý I., Eur. J. Org. Chem., 3849-3857 (2011).

32) Yavari K., Aillard P., Zhang Y., Nuter F., Retailleau P., Voituriez A., Marinetti A., Angew. Chem. Int. Ed. Engl., 53, 861-865 (2014).

33) Tsujihara T., Inada-Nozaki N., Takehara T., Zhou D.-Y., Suzuki T., Kawano T., Eur. J. Org. Chem., 4948-4952 (2016).

34) Scherubl H., Fritzsche U., Mannschreck A.,
Chem. Ber., 117, 336-343 (1984).

35) Garcia Y., Schoenebeck F., Legault C. Y., Merlic C. A., Houk K. N., J. Am. Chem. Soc., 131, 6632-6639 (2009).

36) Hesse S., Kirsch G., Synthesis, 5, 0755-0758 (2001).

37) Bagi P., Fekete A., Kállay M., Hessz D., Kubinyi M., Holczbauer T., Czugler M., Fogassy E., Keglevich G., Chirality, 26, 174182 (2014).

38) Yamamoto K., Shimizu T., Igawa K., Tomooka K., Hirai G., Suemune H., Usui K., Sci. Rep., 6, 36211 (2016).

39) Allen D. W., Taylor B. F., J. Chem. Soc. Dalton Trans., 51-54 (1982).

40) Trost B. M., Crawley M. L., Chem. Rev., 103, 2921-2944 (2003).

41) Lu Z., Ma S., Angew. Chem. Int. Ed. Engl., 47, 258-297 (2008).

42) Trost B. M., Zhang T., Sieber J. D., Chem. Sci., 1, 427-440 (2010).

43) Cheung H. Y., Yu W.-Y., Lam F. L., AuYeung T. T.-L., Zhou Z., Chan T. H., Chan A. S. C., Org. Lett., 9, 4295-4298 (2007).

44) Zhang D., Wang Q., Coord. Chem. Rev., 286, 1-16 (2015).

45) Yamamoto T., Akai Y., Nagata Y., Suginome M., Angew. Chem. Int. Ed. Engl., 50, 88448847 (2011).

46) Cammidge A. N., Crépy K. V. L., Chem. Commun., 1723-1724 (2000).

47) Yin J., Buchwald S. L., J. Am. Chem. Soc., 122, 12051-12052 (2000).

48) Shen X., Jones G. O., Watson D. A., Bhayana B., Buchwald S. L., J. Am. Chem. Soc., 132, 11278-11287 (2010).

49) Zhou Y., Zhang X., Liang H., Cao Z., Zhao X., He Y., Wang S., Pang J., Zhou Z., Ke Z., Qiu L., ACS Catal., 4, 1390-1397 (2014).

50) Xu G., Fu W., Liu G., Senanayake C. H., Tang W., J. Am. Chem. Soc., 136, 570-573 (2014). 